\title{
Liana HURSKA-KOWALCZYK
}

Uniwersytet Szczeciński

\section{Aspiracje Ukrainy wobec Unii Europejskiej}

\section{Wstęp}

$\mathrm{D}$ otychczas Unia Europejska (UE) w swoich relacjach z Ukrainą opierała się na Porozumieniu o Partnerstwie i Współpracy oraz Wspólnej Strategii UE wobec Ukrainy. Dokumenty te nie przewidują perspektywy nabycia członkostwa przez Ukrainę. Po rewolucji pomarańczowej uwypukliły się nowe perspektywy w relacjach między Ukrainą a UE, które Ukraina nie potrafiła z rożnych powodów (zarówno wewnątrzpolitycznych, jak i problemów w środowisku wspólnoty europejskiej) wykorzystać. Zwłaszcza podczas dziewiątego szczytu Ukraina-UE 1 grudnia 2005 r. podpisano szereg ważnych dwustronnych dokumentów: Umowę o współpracy w zakresie cywilnego globalnego systemu nawigacji satelitarnej (GNSS); Umowę między Ukrainą a UE o niektórych aspektach połączenia powietrznego, Memorandum o wzajemnym porozumieniu w stosunku współpracy między Ukrainą a UE w dziedzinie energetycznej. Została również upubliczniona decyzja UE o nadaniu Ukrainie statusu państwa o gospodarce rynkowej oraz uzgodniono kwestie dotyczące rozpoczęcia negocjacji o uproszczeniu reżimu wizowego. Podczas dziesiątego szczytu Ukraina-UE potwierdzono zamiar rozpoczęcia w 2007 r. negocjacji o zawarciu nowej zasadniczej umowy między Ukrainą a UE. Elity rządzące Ukrainy oczekują, że nowa umowa będzie zawierała punkty dotyczące perspektywy członkostwa Ukrainy w Unii Europejskiej.

\section{Ewolucja stosunków między Ukrainą a Unią Europejską}

Relacje między Ukrainą a Unią Europejską zaczęły się w 1991 r. po uzyskaniu niepodległości przez państwo ukraińskie. 2 grudnia 1991 r. minister ds. zagranicznych Holandii, która przewodniczyła wówczas w UE, w oficjalnym liście uznał niepodległość Ukrainy w imieniu Unii Europejskiej. Podkreślił, iż referendum ogólnoukraińskie z 1 grudnia 1991 r. 
odbyło się zgodnie z zasadami demokratycznymi i zaprosił Ukrainę do podtrzymywania otwartego dialogu z Unią Europejską ${ }^{1}$.

Pierwsze spotkanie „Ukraina-UE” na najwyższym szczeblu odbyło się 14 września 1992 r., z udziałem ówczesnego prezydenta Ukrainy Leonida Krawczuka oraz przewodniczącego Komisji Europejskiej Jacques Delors. Jego wymiernym rezultatem było otwarcie w październiku 1993 r., w Kijowie przedstawicielstwa Komisji Europejskiej (analogicznie w lipcu 1995 r. w Brukseli otwarto przedstawicielstwo Ukrainy przy Wspólnotach Europejskich). Podczas tego spotkania uchwalono także decyzję o przeprowadzeniu konferencji „Ukraina-«Trójka UE» (pierwsza z nich odbyła się 9-14 marca 1994 r.). Ówczesny prezydent Ukrainy L. Krawczuk wydał 28 sierpnia 1993 roku zarządzenie o utworzeniu Międzyresortowego Komitetu ds. Wspólnot Europejskich (w 1995 r. prezydent Leonid Kuczma zmienił jego nazwę na Międzyresortowy Komitet ds. Unii Europejskiej). Komitet miał „uzgadniać i koordynować politykę Ukrainy wobec Unii Europejskiej"2.

W 1992 r. rozpoczęto negocjacje w sprawie Porozumienia o Partnerstwie $i$ Wspótpracy między Ukrainq a Uniq Europejskq - zasadniczej podstawy prawnej stosunków Ukrainy i Unii. Porozumienie zostało podpisane 16 czerwca 1994 r. Akt ten nabrał mocy prawnej 1 marca 1998 r., po ratyfikowaniu go przez państwa członkowskie Unii Europejskiej. W czerwcu 1996 r. UE nadała Ukrainie status państwa o gospodarce przejściowej. Następnie Parlament Europejski podjął decyzję o opracowaniu Wspólnej Strategii UE wobec Ukrainy. Została ona zatwierdzona przez Komisję Europejską w Helsinkach 11 grudnia 1999 r.

Dla stosunków Ukrainy z UE przełomowe znaczenie miały wydarzenia w 2004 r. Rozszerzenie Wspólnoty o dziesięć nowych państw, uczyniło Ukrainę jej bezpośrednim sąsiadem. W tej sytuacji Unia Europejska opracowała nowe zasady postępowania wobec państw sąsiadujących, które zostały określone jako Europejska Polityka Sąsiedztwa (EPS). Koncepcja EPS została zaprezentowana przez Komisję Europejską jeszcze w maju 2003 r. (pod nazwą Inicjatywa Szerszej Europy); z kolei szczegółowe opracowanie znalazło swój wyraz w Dokumencie Strategicznym Europejskiej

S. Jewanhełos, Do UE ne tak dateko, jakshcho pryskoryty chodu, „Wicze” 1996, nr 12, s. 102-111.

${ }^{2}$ Ukaz Prezydenta Ukrajiny wid 28 serpnia 1993 № 358/93. Pro Miżwidomczyj komitet Ukrajiny u sprawach Jewropejśkych Spilnot, http://uazakon.com/documents/date_5s/pg_irwasm.htm/. 
Polityki Sąsiedztwa, który Rada Europejska zatwierdziła w czerwcu 2004 r. W ramach EPS przygotowano na okres 3-5 lat odrębnie dla każdego kraju Plany Działań. Pierwszy taki Plan Działań Ukraina-UE został opracowany w 2004 r. jeszcze za prezydentury L. Kuczmy. Po rewolucji pomarańczowej w listopadzie-grudniu 2004 r. do tego Planu Działań UE dołączyła 10-punktowy Aneks, który zawierał dodatkowe postanowienia, nie zmieniał i nie uzupełniał jednak w zasadniczy sposób postanowień Planu. Podczas posiedzenia Rady ds. współpracy Ukraina-UE w Brukseli 21 lutego 2005 r. został przyjęty dokument Plan Działań Ukraina-UE 2005-2007 wraz z Aneksem. W trakcie realizacji Planu Działań Ukraina-UE w grudniu 2005 r. Rada Unii Europejskiej nadała Ukrainie statusu państwa o gospodarce rynkowej. Ważnym wydarzeniem było również podjęcie decyzji o podpisaniu Porozumień o uproszczeniu reżimu wizowego i readmisji, które były parafowane 27 października 2006 r. podczas kolejnego szczytu Ukraina-Unia Europejska w Helsinkach. Porozumienia te zostały podpisane 18 czerwca 2007 r. w trakcie posiedzenia Rady ds. Współpracy Ukraina-Unia Europejska w Luksemburgu, a następnie ratyfikowane przez Parlament Europejski w Strasburgu 13 listopada 2007 r. W Porozumieniu wizowym przewidywano uproszczenie otrzymywania wiz przez obywateli ukraińskich. Porozumienie o readmisji zawierało przepisy dotyczące regulacji deportacji nielegalnych imigrantów z Unii Europejskiej na Ukrainę, gdyby było udowodnione, iż przybyli oni z terytorium państwa ukraińskiego. Powyższe porozumienia w pełni wejdą w życie dopiero wtedy, gdy będzie przygotowana podstawa prawna i techniczna (np. zostaną wybudowane ośrodki, w których będą umieszczeni wydaleni z UE imigranci).

Następnie Plan Działań Ukraina-UE 2005-2007 został przedłużony na 2008 r. 16 maja 2008 r. Ukraina stała się pełnoprawnym 152 członkiem Światowej Organizacji Handlu (WTO).

Jednocześnie Unia i Ukraina przystapiły do opracowania nowego zasadniczego Porozumienia, gdyż ważność poprzedniego skończyła się w lutym 2008 roku $^{3}$. Ukraińska strona niejednokrotnie oświadczała, iż ta regulacja powinna być umową o stowarzyszeniu ${ }^{4}$, która przewidywałaby perspektywę członkostwa Ukrainy w UE. Z kolei Rada UE zasygnalizo-

3 Zasadniczy termin jego działania wynosił 10 lat z możliwością następnego automatycznego prolongowania pod warunkiem, że żadna ze stron sygnatariuszy nie będzie miała do niego zastrzeżeń.

4 Szczodo układennia nowoji posyłennoji uhody miż Ukrajinoju ta UE, http://www.mzs.dn.ua/index.php?p=45. 
wała, że nowe Porozumienie między Ukrainą a Unią nie powinno określać rozwoju ich relacji w przyszłości, czyli tym samym UE nie chce w nowej umowie określać perspektywy nabycia członkostwa przez Ukrainę.

Natomiast Unia Europejska rozwijając Europejska Politykę Sasiedztwa opracowała w jej ramach specjalny program dla państw-sąsiadów z Europy Wschodniej i Kaukazu Południowego zatytułowany, jako Partnerstwo Wschodnie. Oficjalna inauguracja programu odbyła się podczas szczytu „Partnerstwo Wschodnie” 7 maja 2009 r. w Pradze. Objął on sześć państw: Ukrainę, Gruzję, Armenię, Azerbejdżan, Mołdawię oraz Białoruś. Program jest ukierunkowany na rozwój współpracy UE z wymienionymi państwami, nie przewiduje z kolei ich ewentualnego przyszłego członkostwa w Unii. Fakt ten wywołuje w części elity politycznej Ukrainy widoczne niezadowolenie ${ }^{5}$, gdyż władze ukraińskie niejednokrotnie podkreślały, iż celem Ukrainy jest członkostwo w Unii Europejskiej.

\section{Aspiracje władz Ukrainy w kierunku integracji z UE}

Wolę wejścia Ukrainy w struktury europejskie deklarowały jeszcze władze Ukraińskiej SRR, gdy Rada Najwyższa USRR w Postanowieniu o realizacji Deklaracji o państwowej suwerenności Ukrainy $w$ dziedzinie stosunków zagranicznych z 25 grudnia 1990 r. zobowiązała rząd „skierować wysiłki na zabezpieczenie bezpośredniego udziału Ukraińskiej SRR w ogólnoeuropejskim procesie oraz strukturach europejskich" ${ }^{\text {. }}$

Aspiracje integracji Ukrainy z Unią Europejską zostały sformułowane przez parlament niepodległej Ukrainy w 1993 r. W Postanowieniu o głównych kierunkach polityki zagranicznej Ukrainy z 2 lipca 1993 r. stwierdzono, że „celem ukraińskiej polityki zagranicznej jest w perspektywie członkostwo we Wspólnotach Europejskich, a także innych organizacjach zachodnioeuropejskich bądź ogólnoeuropejskich, pod warunkiem, iż nie będzie zagrażało to interesom narodowym"7. W Postanowieniu

5 Zob. np. A. Czechanowicz, ,S Schidne Partnerstwo” rozczarowuje, http://inozmi.glavred.info/articles/1248.html.

${ }^{6}$ Pro realizaciju Dekłaraciji pro derżawnyj suwerenitet Ukrajiny w sferi zownisznuch znosyn, Werchowna Rada URSR, Postanowa № 581-XII wid 25.12.1990, http://www.uapravo.net/data2008/base65/ukr65695.htm.

Osnowni napriamky zownisznioji polityky Ukrajiny: postanowa Werchownoji Rady Ukrajiny wid 2 typnia 1993 r., w: Ukrajina na miżnarodnij areni. Zbirnyk dokumentiw i materialiw 1991-1995 rr., t. 1, Kyjiw 1998, s. 41-42. 
Rady Najwyższej Ukrainy również podkreślono, iż Ukraina zawrze Porozumienie o Partnerstwie $i$ Wspótpracy z UE w celu podtrzymywania stabilnych relacji i powinno stać się ono pierwszym etapem w kierunku podążania „do członkostwa stowarzyszeniowego, a następnie nabycia pełnego członkostwa w tej organizacji”. Jeszcze w styczniu 1992 r. ówczesny prezydent Ukrainy L. Krawczuk oświadczył, że Ukraina wybrała kierunek integracji ze Wspólnotą. Następnie podczas podpisania Porozumienia o Partnerstwie i Wspótpracy 14 czerwca 1994 r. potwierdził on swoje oświadczenie.

9 czerwca 1998 r. władze ukraińskie oficjalnie ogłosiły chęć nabycia przez Ukrainę statusu członka stowarzyszonego UE. Ówczesny prezydent Ukrainy L. Kuczma w zarządzeniu nr 615/98 z 11 czerwca 1998 r. zatwierdził Strategię integracji Ukrainy z Uniq Europejska. W tej Strategii określono dziewięć „głównych kierunków procesu integracyjnego”: 1) adaptacja ustawodawstwa Ukrainy do regulacji prawnych UE, zagwarantowanie praw człowieka; 2) integracja gospodarcza oraz rozwój relacji handlowych między Ukrainą a UE; 3) integracja Ukrainy z UE w kontekście bezpieczeństwa ogólnoeuropejskiego; 4) konsolidacja polityczna i wzmocnienie demokracji; 5) adaptacja polityki społecznej do standardów UE; 6) integracja kulturowo-edukacyjna i naukowo-techniczna; 7) regionalna integracja Ukrainy; 8) współpraca w różnych dziedzinach; 9) współpraca w zakresie ochrony środowiska?

6 grudnia 1999 r. odbyło się spotkanie Prezydenta Ukrainy L. Kuczmy z ówczesnym przewodniczącym Komisji Europejskiej Romanem Prodi. Podczas tego spotkania Prezydent Ukrainy ogłosił o zamiarach podpisania przez Ukrainę umowy o członkostwie stowarzyszonym z UE już 2007 r., a około 2011 r. stania się członkiem Stowarzyszenia Europejskiego (nie Unii) ${ }^{10}$. Swoją deklarację prezydent L. Kuczma potwierdził w Orędziu Prezydenta Ukrainy do Rady Najwyższej Ukrainy „Europejski wybór: konceptualne zasady strategii gospodarczego i społecznego rozwoju Ukrainy w latach 2002-2011"11. Ukraina, jednak, nie podjęła koherent-

8 Ibidem.

9 Stratehija intehraciji Ukrajiny do UE, http://www.mzs.dn.ua/index.php?p=45.

${ }^{10}$ O. Kowalowa, Ukrajina - Jewropejśkyj sojuz: integracijnyj potenciat i probłamy spiwrobitnyctwa, „Ludyna i polityka” 2002, nr 6, s. 23.

${ }_{11}$ Prezydent L. Kuczma zarysował parlamentarzystom ukraińskim następujący plan nabycia przez Ukrainę członkostwa w UE: 1) lata 2002-2003 - Ukraina stanie się członkiem Światowej Organizacji Handlu; 2) lata 2003-2004 - przeprowadzenie 
nych działań na rzecz zbliżenia ze strukturami europejskimi, z kolei Unia nie wysłała konkretnych sygnałów świadczących o możliwości nabycia członkostwa przez Ukrainę. Lata 1991-2004 można określić nie inaczej jak ,integracja werbalna" 12 Ukrainy z Unią Europejską.

Elity postradzieckie nie rozumiały specyfiki procesu integracji europejskiej ${ }^{13}$. Timothy Schneider stwierdził na falach radia „Swoboda”, że na Ukrainie zwracano uwage na mniej znaczące dla Unii czynniki ${ }^{14}$, np. władze ciagle podkreślały, iż Ukraina zawsze była państwem europejskim (według parametrów geograficznych). Ówczesne elity polityczne Ukrainy nie miały świadomości, że we frazie „dołączenie do wspólnoty państw rozwiniętej demokracji” głównym słowem jest nie „dołączenie”, lecz „demokracja”" ${ }^{2}$, a Unia Europejska - jest przede wszystkim zespołem instytucji, norm i reguł, a nie tylko określonym terytorium. W efekcie na Ukrainie nie zostały przeprowadzone reformy, które dostosowałyby jej gospodarkę do standardów wolnego rynku, a wymiar sprawiedliwości do norm prawa UE. Z kolei narastające podczas drugiej kadencji prezydentury L. Kuczmy (lata 1999-2004) tendencje podążania ku autorytaryzmowi odwracały Ukrainę od jakichkolwiek perspektyw jej integracji z Unią. Wysocy urzędnicy UE dawali temu niejednokrotnie wyraz $\mathrm{w}$ rozmowach $\mathrm{z}$ władzami ukraińskimi, co powodowało uściślenie ich współpracy z Rosją. Elity rządzące Ukrainy prowadziły zatem polity-

negocjacji i podpisanie między Ukrainą a UE Umowy o członkostwie stowarzyszonym; 3) lata 2003-2004 przeprowadzenie negocjacji o ukształtowaniu strefy wolnego handlu między Ukrainą i UE; 4) lata 2002-2007 - uporządkowanie ustawodawstwa Ukrainy zgodnie z wymogami ustawodawstwa UE; 5) lata 2004-2007 - wykonanie procedur niezbędnych dla wprowadzenia w życie Umowy o stowarzyszeniu między Ukrainą a UE; 6) lata 2005-2007 - przeprowadzenie negocjacji i ukształtowanie Unii Celnej między Ukrainą a UE; 7) lata 2007-2011 - całkowite wykonanie Umowy o stowarzyszeniu między Ukrainą a UE oraz kryteriów z Kopenhagi dotyczących członkostwa w UE; 8) rok 2011 - ukształtowanie przesłanek dla nabycia przez Ukrainę członkostwa w UE, Jewropejśkyj wybir: Wystup Prezydenta Ukrajiny Ł. D. Kuczmy u Werchownij Radi Ukrajiny 18 czerwnia 2002 roku, Posłannia Prezydenta Ukrajiny do Werchownoji Rady Ukrajiny, Kyjiw 2002, s. 79.

12 T. Wozniak, Stosunky Ukrajina - UE: perezawantażennia, „Ji” 2007, nr 50, http://www.ji.lviv.ua/n50texts/voznyak2.htm.

13 A. Szeptycki, Ukraina i Unia Europejska: Europa od Brestu po Don, „Polski Przegląd Dyplomatyczny” 2006, nr 1 (29), s. 13.

${ }^{14}$ R. Oficynśkyj, Politycznyj Rozwytok nezateżnoji Ukrajiny (1991-2004) w aspekti jewropejśkoji identycznosti, Użhorod 2005, s. 106.

${ }_{15}$ Ibidem. 
kę balansowania między Wschodem a Zachodem, którą określono, jako politykę „wielokierunkową”. Wywoływała ona na Zachodzie nastrój „,Ukrainę fatigué” (,zmęczenie od Ukrainy”) ${ }^{16}$. Brytyjski ekspert w sprawach krajów byłego ZSRR James Sherr zaznaczył, iż takie „relacje Ukrainy z UE podobne są do tańca XVII-wiecznego, w którym partnerzy nigdy nie tańczą razem" $"$.

Według sondażu przeprowadzonego w 2000 r. wśród ekspertów główne przeszkody dla integracji Ukrainy z Unią były następujące: korupcja i zorganizowana przestępczość - 85,3\%; niezdolność liderów państwowych do sformułowania i wprowadzenia strategicznych priorytetów - 64,7\%; wolne tempo przeprowadzenia reform gospodarczych - 61,8\%; odziedziczony radziecki typ myślenia i organizacji społecznej $-26,5 \%{ }^{18}$.

Po rewolucji pomarańczowej nowa ekipa bardzo ambitnie podeszła do kwestii polityki integracji z Unią Europejską. Priorytetowość kierunku eurointegracyjnego $\mathrm{W}$ polityce zagranicznej Ukrainy zadeklarowały wszystkie szczeble władzy państwowej. W swoim apelu do narodu Ukrainy 23 stycznia 2005 r. prezydent Wiktor Juszczenko zaakcentował, że „Nasze miejsce - w Unii Europejskiej. Mój cel - Ukraina w Europie Zjednoczonej”. W programie działalności Gabinetu Ministrów „Naprzeciw ludziom” zaznaczono, że ,integracja europejska stanie się priorytetem działalności międzynarodowej rządu, rząd przejdzie od deklaracji do konkretnych kroków, które doprowadzą stosunki z UE do poziomu o per-

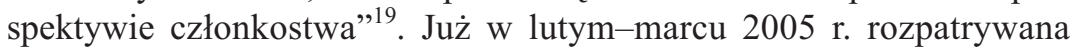
była możliwość podania zgłoszenia o członkostwo w Unii Europejskiej. Następnie jednak sprawujący władzę zgodzili się z rekomendacjami Komisji Europejskiej i odłożyli kwestię zgłoszenia do realizacji Planu o przystapieniu do momentu, zanim Unia Europejska będzie gotowa do pozytywnego rozpatrzenia $\mathrm{go}^{20}$. Po rewolucji pomarańczowej jedynie

${ }^{16}$ M. Riabczuk, Zona widczużennia: ukrajinśka oliharchija miż Schodom i Zachodom, Kyjiw 2004, s. 55, 76.

${ }_{17}$ Cyt. za: R. Oficynśkyj, Politycznyj Rozwytok nezateżnoji..., s. 106.

${ }_{18}$ Monitoring foreign and security policy of Ukraine, Ukrainian Center for Peace, Conversion and Foreign Policy of Ukraine, October, November, December 2000, s. 113.

${ }_{19}$ Zob. Uriadowyj portał, http://www.kmu.gov.ua/control/uk/publish/article.

${ }^{20}$ G. Gromadśkyj, O. Suszko, Miż nadijamy i możlywostiamy: widnosyny UE-Ukrajina za rik po pomaranczewij rewolucji, Warszawa 2005, s. 15 i n. 
Parlament Europejski uznał, iż Ukraina ma prawo ubiegać się o członkostwo w Unii ${ }^{21}$.

Rozpad koalicji pomarańczowej, odwołanie kolejno rządów Julii Tymoszenko i Juria Jechanurowa, przedterminowe wybory w 2007 r., ciaggłe konflikty prezydenta Wiktora Juszczenki z ponownie mianowanym w 2007 r. premierem Julią Tymoszenko oraz inne wydarzenia świadczące o systematycznym kryzysie politycznym na Ukrainie, implikowały coraz bardziej krytyczne spojrzenie na nią Unii Europejskiej. Co więcej ostry konflikt gazowy pomiędzy Ukrainą a Rosją końca 2008 - początku 2009 r. oraz jego rozwiązanie ukazał Zachodowi mocne energetyczne uzależnienie pierwszej od drugiej.

Wiktor Janukowicz wybrany 7 lutego 2010 r. na głowę państwa niejednokrotnie stwierdzał, że nowa umowa między Ukrainą a UE powinna zawierać punkty dotyczące perspektywy jej członkostwa w Unii ${ }^{22}$. W obecnym czasie szczególną uwagę zwraca na to, by jeszcze w 2011 r. została utworzona strefa wolnego handlu między Ukrainą a UE, a także wprowadzono reżim bezwizowy, licząc, że Polska, która obejmuje 1 lipca $2011 \mathrm{r}$. przewodnictwo w Radzie Unii Europejskiej, będzie temu sprzyjać ${ }^{23}$.

\section{Postawy partii politycznych wobec Unii Europejskiej w programach wyborczych}

Dostrzega się jednak widoczny brak konsensusu głównych partii politycznych Ukrainy w stosunku Unii Europejskiej. Świadczy o tym zwłaszcza analiza programów partii politycznych, zwycięzcy wyborów parlamen-

21 Wyniki wyborów na Ukrainie. Rezolucja Parlamentu Europejskiego w sprawie wyników wyborów na Ukrainie, P6_TA(2005)0009, Strasburg, 13 stycznia 2005 r., http://www.europarl.eu.int.

22 Zob. Janukowicz: nasz gławnyj prioritiet - integracyja w JeS (UE), http://ura-inform.com/ru/politics/2011/05/25/integration; Janukowicz naprawlajet Ukrainu w storonu JeS, http://www.i-g-t.org/2011/05/. Z kolei warto podkreślić, że w programie wyborczym W. Janukowicz nie uwzględniał eurointegracji jako kierunku priorytetowego dla Ukrainy, perspektywy relacji między UE a Ukrainą określał jako „partnerstwo strategiczne”. Zob. Peredwyborna prohrama kandydata na post Prezydenta Ukrajiny Janukowycza W. F. ,Ukrajina - dla ludej!”, http://www.yanukovych.com.ua/news-10697.html.

23 Wiktor Janukowicz: w bliżajsziem buduszcziem Ukraina i Jewropa stanut nierazdielnymi, http://newsdiscover.net/news/read/Viktor_Janukovich_v_blizhajshem_buducshem_Ukraina_i_Evropa_stanut_nerazdelnymi.html. 
tarnych z lat: 2006 i 2007. Zdaniem byłego ministra spraw zewnętrznych Borysa Tarasiuka jest to jedna z głównych przyczyn utrudniających podążaniu Ukrainy w kierunku Unii Europejskiej.

W przedwyborczym programie Partii Regionów z 2006 r. nie zawarto osobnego rozdziału o polityce zagranicznej. Kwestia ta była jednak obecna we wszystkich trzech rozdziałach programu wyborczego ${ }^{24}$. W pierwszym rozdziale zaznaczono, że po rewolucji pomarańczowej Ukraina przekształciła się w nieprzewidywalnego, chwiejnego partnera. W drugim postulowano prowadzenie polityki dobrosąsiedzkich relacji ze wszystkimi państwami, z którymi Ukraina ma wspólną granicę. Podkreślono, że należy prowadzić Ukrainę do integracji z Unią Europejską stopniowo i drogą rzeczywistych kroków, licząc się z interesami narodowymi. Zalecano również, aby ostrożnie postępować odnośnie członkostwa w NATO, przeprowadzić referendum ogólnonarodowe w tej sprawie. W trzecim rozdziale pisano o konieczności normalizacji relacji z partnerem strategicznym Ukrainy - Rosją, opowiadano się za ukończeniem wszystkich prac związanych z utworzeniem Wspólnej Przestrzeni Ekonomicznej $(\mathrm{WEP})^{25}$. Możemy wnioskować, że w 2006 r. w priorytetach zewnętrznych Partii Regionów mieściły się dwa wektory polityki zagranicznej: Europa oraz Rosja. Dwukierunkowość ta zachowała się w wyborczym programie Partii Regionów i podczas przedterminowych wyborów w 2007 r. ${ }^{26}$ Program zawierał tezę o zabezpieczeniu zbilansowanej polityki zagranicznej, ,gdzie Wschód (Rosja i państwa Wschodu) i Zachód (państwa UE i Stany Zjednoczone) są kierunkami o jednakowym znaczeniu". Znaczny akcent postawiono na udziale Ukrainy w Wspólnej Przestrzeni Ekonomicznej, partia nadawała „ważnego znaczenia udziałowi Ukrainy w WEP, co poszerzy nasze możliwości w wymianie wzajemnej towarów, kapitałów i usług na rynku euroazjatyckim”. Stwierdzono również, że „,członkostwo w Unii Europejskiej lub Światowej Organizacji Handlu nie jest celem w sobie, lecz środkiem powiększenia dobrobytu naszych obywateli, poszerzenie możliwości ojczystej gospodarki, nauki i oświaty”.

241 rozdział nosił tytuł - Rok Majdanu - rok kłamstwa; 2 - Droga regionów; 3 - Klucze do sukcesu, zob. szerzej Dobrobut-narodu! Władu - regionam! Peredwyborna Programa Partiji Regioniw, „Hołos Ukrajiny” 17 II 2006, nr 31, s. 4.

25 Ibidem, s. 4.

26 Tym razem program przedwyborczy mieścił osobny rozdział o polityce zagranicznej, zob. szerzej Partija Regioniw. Peredwyborna prohrama, http://www.novinar.com.ua/dossiers/bloki_party/party_region/1673. 
W programie wyborczym Wyborczego Bloku Julii Tymoszenko (BJuTy) 2006 r. kwestie stosunków międzynarodowych mieściły się w ostatnim rozdziale „Harmonijna polityka zewnętrzna”. Określono dosyć ogólnie priorytety polityki zagranicznej. Zapisano, że należy „określić ściśle narodowe priorytety Ukrainy oraz zapewnić ich realizację na wszystkich poziomach, polityka zagraniczna powinna realizować się [...] na podstawie równych stosunków ekonomicznych o wygodzie wzajemnej ze wszystkimi państwami, z którymi Ukraina ma wspólne interesy" ${ }^{27}$. W programie wyborczym BJuTy z 2007 r. Ukraiński proryw: ku sprawiedliwości i zdolności konkurencyjnej państwa nie zawarto osobnego punktu o wektorach polityki zagranicznej ${ }^{28}$. Lider Bloku Julija Tymoszenko opowiadała się za nawiązaniem dobrych relacji z poszczególnymi państwami Unii Europejskiej i wyważonym, ostrożnym podążaniem Ukrainy w kierunku UE, pilnując interesów narodowych ${ }^{29}$.

Natomiast Blok „Nasza Ukraina” w programie przedwyborczym z 2006 r. określił ściśle, że integracja Ukrainy ze strukturami europejskimi jest głównym kierunkiem polityki zagranicznej. Zawarte w nim były konkretne obietnice, dotyczące m.in. tego, że Ukraina w 2006 r. stanie się członkiem Światowej Organizacji Handlu, nabędzie status stowarzyszonego członka UE w ściśle określonym terminie ${ }^{30}$ (nie zostały one jednak zrealizowane). Program wyborczy Bloku „Nasza Ukraina - Samoobrona Ludowa" z 2007 r. za główny kierunek polityki zagranicznej nadal uznawał Unię Europejską. Należy zaznaczyć, że stanowisko wobec Unii Europejskiej stało się bardziej pragmatyczne w porównaniu z poprzednimi programami. $\mathrm{W}$ trzecim rozdziale programu konstatowano, że zostanie ukończone „przystapienie do Światowej Organizacji Handlu, co w ciagu 5 lat da do budżetu Ukrainy dodatkowych 25 miliardów grzywien"31. Wspominano również o zamiarze utworzenia strefy wolnego handlu oraz uproszczeniu reżimu wizowego z Unią Europejską.

27 Prohrama Wyborczoho Błoku politycznych partij „Błok julii Tymoszenko”, „Hołos Ukrajiny” 10 II 2006, nr 26, s. 4.

28 Peredwyborna prohrama BJuT, http://www.novynar.com.ua/dossiers/bloki_party/block_byt/1645.

${ }^{29}$ Julija Tymoszenko: Ukrajini Ne potribno pospiszaty do UE i NATO, http://www.tymoshenko.com.ua/ukr/news/first/2617/.

30 Ukrajina u nas odna!: Peredwyborna prohrama Błoku „Nasza Ukrajina”, „Hołos Ukrajiny” 23 II 2006, s. 4.

31 Peredwyborna prohrama Błoku „Nasz Ukrajina - Narodna Samooborona”: „Dla ludej - a Ne politykiw!”, http://www.razom.org.ua/ua/static/programme/. 
Socjalistyczna Partia Ukrainy (SPU) w epigrafie programu wyborczego z 2006 r. zapisała hasło „Zbudujemy Europę w Ukrainie!”. W 20 punkcie programu zaznaczono, że SPU stawia na relacje dobrego sąsiedztwa z Rosją oraz innymi państwami ${ }^{32}$. W programie wyborczym z 2007 r. nie wymieniono punktów odnoszących się do polityki zagranicznej ${ }^{33}$.

Komunistyczna Partia Ukrainy (KPU) w programie wyborczym z 2006 r. nie określała jakichkolwiek pozycji odnośnie stosunków z Unią Europejską. Priorytetem polityki zagranicznej Ukrainy według KPU powinny być relacje z państwami WNP i przystąpienie do $\mathrm{WEP}^{34}$. Partia kategorycznie nie dopuszczała przystapienia Ukrainy do agresywnego" bloku NATO ${ }^{35}$. W wyborczym programie z 2007 r. KPU stała konsekwentnie na swoich pozycjach odnośnie polityki zagranicznej Ukrainy. Jednak pojawiła się opcja, że przystappienie do gospodarczych i politycznych organizacji międzynarodowych, a także udział w procesach integracyjnych będą realizowane zgodnie $\mathrm{z}$ interesami narodowymi według wyników referendum ogólnonarodowego ${ }^{36}$.

W wyborczym programie z 2006 r. Ludowy Blok Łytwyna stawił za cel uczestnictwo Ukrainy we wszystkich organizacjach międzynarodowych, które są korzystne dla interesów narodowych, politykę balansowania w stosunkach z państwami - kluczowymi partnerami, strategię wyjątkowych relacji z Rosją oraz wzmocnienie solidarności słowiańskiej ${ }^{37}$. Ludowy Blok Łytwyna w swoim programie wyborczym podczas przedterminowych wyborów parlamentarnych 2007 r. opowiadał się za prowadzeniem polityki zagranicznej na podstawie interesów narodowych oraz za zachowaniem ,aktywnej neutralności”. O przystąpieniu Ukrainy do

32 Zbudujemy Jewropu w Ukrajini: Predwyborna prohrama Socialistycznoji partiji Ukrajiny do wyborów u Werchownu Radu 2006 roku, „Hołos Ukrajiny” 11 II 2006, nr 27, s. 5.

33 Peredwyborna prohrama SPU, http://www.novynar.com.ua/dossiers/bloki_party/society_party/1647.

34 Władu $i$ własnist' - trudowomu narodu Ukrajiny!: Peredwyborna prohrama Komunistycznoji partiji Ukrajiny, „Hołos Ukrajiny” 18 III 2006, nr 50, s. 4; Peredwyborna prohrama KPU do wyborów u WR Ukrajiny 2002 r. „Komunisty peremożut' - Ukrajina wyhraje!", http://www.parlament.org.ua.

35 Ibidem.

36 Za narodowładdia! Het' dyktaturu!: Peredwyborna prohrama Komunistycznoji partiji Ukrajiny, http://www.kpu.km.ua/vibor2007/other/other_3.php.

37 Narodnist', sprawedlywist', zakonnist': Prohrama Narodnoho Btoku Łytwyna, „Hołos Ukrajiny” 10 III 2006, nr 44, s. 4. 
organizacji międzynarodowych powinno się decydować w drodze ogólnoukraińskiego referendum ${ }^{38}$.

Przy sporządzeniu swoich programów partie polityczne Ukrainy dosyć często orientowały są na to, aby zachęcić do głosowania na siebie obywateli. Określając priorytety polityki zagranicznej partie polityczne biorą pod uwagę postawy obywateli Ukrainy wobec innych państw oraz organizacji międzynarodowych.

\section{Postawy społeczeństwa ukraińskiego wobec UE}

Ciekawe są pod tym względem badania rosyjskiej fundacji „Opinia publiczna" przeprowadzone we wszystkich regionach Ukrainy w styczniu-lutym 2006 r. Polityków orientujących się na Rosję wsparłoby od 38 do $41 \%$ respondentów, orientujących się na Rosję i jednocześnie na Zachód - od 36 do 38\%, wyłącznie orientujących się na Zachód - 14-15\% pytanych obywateli ${ }^{39}$.

Według danych sondaży ogólnoukraińskich przeprowadzanych przez różne centra socjologiczne Ukraińcy zwykle nadają przewagę dwom kierunkom zewnątrz-politycznym: Rosji i UE. Według wyników badań Ukraińskiego Centrum Badań Ekonomicznych i Politycznych im. Aleksandra Razumkowa w ciagu lat 2004-2007 były dwa okresy obniżenia stopnia wsparcia społecznego współpracy Ukrainy z Unią Europejską. Pierwszy nastapił podczas wyborczej kampanii prezydenckiej w lipcu-listopadzie 2004 r., za współpracą z UE opowiadało się wówczas tylko 25,6\% obywateli; co było spowodowane stosowaniem propagandy antyzachodniej. Po objęciu stanowiska prezydenta przez Wiktora Juszczenkę, w którego kampanii przedwyborczej lansowano hasła proeuropejskie, poparcie dla współpracy z Unią wzrosło, w kwietniu 2005 r. popierało ją 39,6\% obywateli $^{40}$. Drugi okres obniżenia poziomu wsparcia społecznego dla współpracy Ukrainy z UE nastapił podczas wyborczej kampanii w 2006 r. (parlamentarnej) również na skutek szerokiej kampanii antyzachodniej. W tych dwu okresach wzrastała liczba zwolenników współpracy z Rosją.

38 Peredwyborna prohrama Błoku Lytwyna, http://narodna.org.ua/news/2007/07/ $18 / 4293 /$.

${ }^{39}$ Gieopoliticzieskije orijentacyi. Baza dannych Fonda „Obszcziestwiennoje mnienije”, http://www.bd.fom.ru/cat/frontier/countries/Ukraina/geopolitics_ukr.

40 Jewropejśka integracja Ukrajiny: hromadśka dumka, „Nacionalna bezpeka i oborona" 2007, nr 5(89), s. 51. 
Orientacje geopolityczne obywateli Ukrainy związane są z odmiennościami regionalnymi. Na zachodzie Ukrainy wśród obywateli jest widoczna orientacja na kontakty z Unią Europejską, na południu i wschodzie - z Rosją. Odmienności nabyły cech stabilności w ostatnich latach. Według sondażu przeprowadzonego przez Centrum Razumkowa na przełomie 2005/2006 r. dla większości obywateli obwodów Zachodniej Ukrainy priorytetowymi były relacje z państwami Unii Europejskiej (58,8\%), dla większości obywateli wschodu i południa Ukrainy - relacje z Rosją, (odpowiednio - 62,1 i 56,6\%) $)^{41}$. 64,4\% obywateli z Ukrainy Zachodniej zgadzało się z koniecznością przystapienia do Unii Europejskiej, podczas gdy $45 \%$ na wschodzie oraz $54,4 \%$ na południu były temu przeciwnych ${ }^{42}$. Według danych Centrum Razumkowa z przełomu 2005/2006 r. wśród priorytetów obywateli Ukrainy pierwsze miejsce posiadały stosunki z Rosją - 42,2\%, drugie - z państwami Unii Europejskiej - 25,4\%, trzecie - $\mathrm{z}$ innymi państwami WNP $-12 \%{ }^{43}$.

W okresie od grudnia 2006 r. do kwietnia 2007 r. na wschodzie i południu wzrosła liczba respondentów nadających przewagę kontaktom z Rosją (na wschodzie aż do 68,1\%).

W okresie od 12 po 26 grudnia 2009 r. Fundacja „Inicjatywy demokratyczne” wraz z „Ukrainian sociology serwice” przeprowadziła sondaż, którego wyniki wskazały, iż gdyby referendum o przystąpieniu Ukrainy do UE odbyło się w grudniu 2009 r. większość Ukraińców (51\%) opowiedziałoby się „za” przystappieniem, z kolei 27\% - „przeciw”. Wysoki stopień poparcia dołączenia Ukrainy do UE wyrazili obywateli zachodu Ukrainy (68,5\% - ,za”, 11\% - „przeciw”) oraz centrum i północnego-wschodu (,za” - 54\%, ,przeciw” - 20,5\%). Niższy stopień poparcia zademonstrowali obywatele południa i południowego-wschodu Ukrainy (,za" - 43\%, ,przeciw” - 31\%). Najbardziej niski stopień poparcia okazał się w Donbasie i na Krymie (,za”-39\%, „przeciw”- 50\%)

${ }^{41}$ Rehionalni osoblywosti idejno-politycznych orijentacij hromadian Ukrajiny. "Czutlywi” temy w konteksti peredwybornoji kampaniji. Rezultaty sociolohicznoho dostidżennia prowedenoho sociołohicznoju stużboju Centru Razumkowa z 20 po 27 hrudnia 2005 r. 23.02.2006, http://cupol.brama.com/newsite/cupol/uploads/media/Razumkow_polls.htm.

${ }^{42}$ Ibidem.

43 Ibidem.

44 Zob. szerzej: Rezultaty zahalnonacionalnoho sociolohicznoho opytuwannia szczodo czlenstwa Ukrajiny w NATO ta JeS, http://dif.org.ua/ua/press/hdthdrt. 
Oprócz tego większość obywateli Ukrainy (58\%) popiera przystąpienie Ukrainy do Wspólnej Przestrzeni Ekonomicznej z Rosją, Białorusią oraz Kazachstanem. Przeciwnych temu jest tylko 20\% pytanych. Poparcie różni się w wymiarze regionalnym: na zachodzie Ukrainy popiera go jedynie $13 \%$ pytanych, w centrum i północnym wschodzie - $51 \%$, na południu i południowym-wschodzie - 73\%, z tym że w regionie Donbasu i na Krymie za przystapieniem do Wspólnej Przestrzeni Ekonomicznej opowiedziało $93 \%$ pytanych $^{45}$. Widoczna jest zatem dezorientacja części obywateli ukraińskich odnośnie preferencji wektorów polityki zagranicznej. Z badań wynika, że istotna część Ukraińców chciałaby jednocześnie przystąpić do UE i uściślić relacje z Rosją, wstępując do WEP.

\section{Partnerstwo Wschodnie}

Odpowiedzią Unii Europejskiej na aspiracje eurointegracyjne Ukrainy stał się projekt Partnerstwa Wschodniego. Idea tego projektu pojawiła się w 2007 r. i należy do Polski. Następnie była poparta przez Szwecję. Podczas spotkania ministrów ds. zagranicznych UE 26 maja 2008 r., szefowie dyplomacji Polski i Szwecji zaprezentowali wspólny dokument pod tytułem Partnerstwo Wschodnie Unii Europejskiej. Projekt ten został następnie zaakceptowany przez Radę UE 20 czerwca 2008 r. 3 grudnia 2008 r. Komisja Europejska wydała komunikat Partnerstwo Wschodnie skierowany do Parlamentu i Rady, w którym przedstawiła potrzebę zintensyfikowania stosunków z państwami Europy Wschodniej i Kaukazu Południowego ${ }^{46}$. W komunikacie podkreślono, że ,partnerstwo [...] powinno stanowić trwały sygnał polityczny solidarności UE oraz wymiernego wsparcia dla prowadzonych w tych państwach demokratycznych reform o charakterze rynkowym, a także dla konsolidacji ich państwowości oraz integralności terytorialnej" ${ }^{47}$. W komunikacie również podkreślono, że kwestią zasadniczą jest dyferencyjne podejście do każdego

45 Ibidem.

46 W. Martyniuk, Schidne Partnerstwo: finiszna priama do zatwerdzennia, http://www.ucipr.kiev.ua/modules.php?op=modload\&name=News\&file=article\&sid= $603276874 \&$ mode $=$ thread\&order $=0 \&$ thold $=0$.

47 Communications from the Commission to the European Parliament and the Council „Eastern Partnership”, Brussels, 3 December 2008, http://ec.europa.eu/external_relations/eastern/docs/com08_823_en.pdf. 
państwa-partnera (powinno ono zależeć od skuteczności reform wewnętrznych przeprowadzanych przez państwa-sąsiadów). W komunikacie Komisji Europejskiej wspomniano także o perspektywie stowarzyszenia politycznego i integracji gospodarczej z państwami, których dotyczyło Partnerstwo Wschodnie ${ }^{48}$. Przed posiedzeniem 23 lutego 2009 r. Rady UE Komisarz ds. zagranicznych i EPS Benita Ferrero-Waldner zaznaczyła, że Partnerstwo Wschodnie jest instrumentem intensyfikacji EPS ${ }^{49}$.

Czynnikami stymulującymi uchwalenie programu Partnerstwa Wschodniego była przede wszystkim wojna gruzińsko-rosyjska w sierpniu $2008 \mathrm{r}$. oraz rosyjsko-ukraiński kryzys gazowy w grudniu 2008-styczniu 2009 r. Uwidoczniły one UE, że bezpieczeństwo i pokój w Europie Wschodniej i Kaukazie Południowym są gwarancjami bezpieczeństwa Unii.

Rada UE 19-20 marca 2009 r. zatwierdziła wyżej wymieniony komunikat Komisji Europejskiej wraz z inicjatywą Partnerstwo Wschodnie. Wyłączyła z niego punkty o zawarciu umów o stowarzyszeniu wraz $z$ rozpoczęciem natychmiastowego utworzenia strefy wolnego handlu ${ }^{50}$. We Wspólnej deklaracji praskiego szczytu Partnerstwa Wschodniego z 7 maja 2009 r., który uruchomił program Partnerstwa, znalazło się jedynie sformułowanie, że ,głównym celem Partnerstwa Wschodniego jest stworzenie warunków koniecznych do przyspieszenia politycznego stowarzyszenia i dalszej gospodarczej integracji między Unią Europejską a zainteresowanymi państwami partnerskimi" ${ }^{51}$. Dla osiagnięcia tego celu UE będzie „dążyć do wspierania reform politycznych i społeczno-ekonomicznych państw partnerskich" 52 . W deklaracji zostały wymienione następujące płaszczyzny współpracy UE z Ukrainą, Gruzją, Azerbejdżanem, Armenią, Mołdową oraz Białorusią w ramach Partnerstwa Wschodniego: utworzenie strefy wolnego handlu oraz liberalizacja ruchu wizowego w długoterminowej perspektywie; rozwój instytucji administracyjnych państw-partnerów UE; zwiększenie bezpieczeństwa energetycznego;

48 Ibidem.

49 Eastern Partnership - an ambitious project for 21st century European foreign policy, by European Commissioner for External Relations and European Neighbourhood Policy, Benita Ferrero-Waldner, 20 February 2009, http://ec.europa.eu/external_relations/eastern/docs/eastern_partnership_article_bfw_en.pdf.

${ }^{50}$ - A. Honczaruk, Ukrajina pidtrymuje „Schidne partnerstwo” jak instrument dosiagnennia czlenstwa w UE, http://ukraine-nato.ukrinform.ua/ua/analytical/1859/.

${ }^{51}$ Wspólna deklaracja praskiego szczytu Partnerstwa Wschodniego, ttp//:www.premier.gov.pl/templates/admin/userfiles/files/8780_Wspolna\%20deklaracja.doc.

${ }^{52}$ Ibidem. 
stworzenie bliższych więzi między samymi państwami partnerskimi ${ }^{53}$. Partnerstwo Wschodnie zatem ma dodać „rozmachu gospodarczemu, społecznemu i regionalnemu rozwojowi państw partnerskich"54, przyczynić się do intensyfikacji współpracy między państwami sąsiadami UE objętymi programem Partnerstwa Wschodniego. Na realizację tego projektu UE planuje wydać 600 mln euro do 2013 roku - najpierw 350, a później jeszcze 250.

Władze ukraińskie starały się, aby Partnerstwo Wschodnie przewidywało jasną perspektywę członkostwa. Elity rządzące Ukrainy postulowały utworzenie co najmniej dwóch polityk sąsiedztwa - jednej dla krajów aspirujących do uzyskania członkostwa w UE, drugiej zaś dla pozostałych sąsiadów Europy, czego nie dało się jednak osiagnąć.

Z perspektywy ukraińskiej projekt Partnerstwa Wschodniego stał się więc, przede wszystkim instrumentem służącym wyodrębnieniu dotychczas „wrzuconych do jednego kosza adresatów EPS”, tj. państw Afryki i Bliskiego Wschodu oraz krajów europejskich, w tym Ukrainy. Oprócz tego Unia Europejska liczy, iż Ukraina odegra kluczową rolę w trakcie realizacji programu Partnerstwa. O tym niejednokrotnie mówili wysocy urzędnicy Unii. Kwestie te akcentował zwłaszcza przewodniczący Parlamentu Europejskiego Hans-Gert Pöttering podczas swojej wizyty na Ukrainie w kwietniu 2009 r. $^{55}$

\section{Kwestia zawarcia nowej umowy między Ukrainą a Unią Europejską}

W maju 2006 r. rozpoczęto nieoficjalne konsultacje między UE a Ukrainą w sprawie podpisania nowej umowy. Z kolei oficjalne negocjacje ruszyły 5 marca 2007 r. po wizycie Trójki UE w Kijowie 6 lutego 2007 r. ${ }^{56}$ Podczas tej wizyty podjęto następujące decyzje: przeprowadzać regularne spotkania delegacji Ukrainy i UE naprzemiennie w Kijowie i w Brukseli; wyznaczono datę pierwszego spotkania i ułożono ogólny harmonogram kolejnych spotkań; postanowiono utworzyć kilka roboczych grup i pod-

53 Ibidem.

54 Ibidem.

55 W. Martyniuk, Prahmatyczni pohlady Prezydenta Jewropejśkogo Parlamentu na jewropejśku intehraciju Ukrajiny, http://eu.prostir.ua/library/234054.html.

56 Pres-reliz Predstawnyctwa Jewropejśkoji Komisji w Ukrajini wid 8 lutoho 2007 r. ,pokładeno start peremowynam pro uktadennia rozszyrenoji uhody miż UE ta Ukrajinoji”, http://www.delukr.ec.europa.eu/press_releases_uk.html. 
grup opracowujących kierunki współpracy; w pierwszych stadiach procesu negocjacyjnego skoncentrować się na treści umowy, a jej tytuł, który odzwierciedlałby zawartość, określić dopiero pod koniec negocjacji ${ }^{57}$.

W celu wypracowania umowy powołano cztery wspólne negocjacyjne grupy robocze, opracowujące cztery podstawowe aspekty nowej umowy: 1) dialog polityczny, kwestie polityki zagranicznej i bezpieczeństwa; 2) kwestie związane z wymiarem sprawiedliwości, wolnością oraz bezpieczeństwem; 3) współpraca gospodarcza oraz kwestie związane z rozwojem potencjału ludzkiego; 4) zagadnienia dotyczące strefy wolnego handlu (zaczęto je opracowywać dopiero po wejściu Ukrainy w 2008 r. do Światowej Organizacji Handlu).

Władze ukraińskie określiły swoją postawę wobec nowej umowy: powinna to być umowa o stowarzyszeniu z UE zawierająca wzmiankę o przyszłym członkostwie Ukrainy ${ }^{58}$. Wspólne pozycje w tej sprawie na początku procesu negocjacji zajęły, przynajmniej na poziomie oświadczeń, ówczesny prezydent Wiktor Juszczenko, premier Wiktor Janukowicz oraz Rada Najwyższa ${ }^{59} .22$ lutego 2007 r. Rada Najwyższa Ukrainy uchwaliła Postanowienie o oświadczeniu Rady Najwyższej Ukrainy o rozpoczęciu negocjacji między Ukraina a UE $w$ sprawie zawarcia nowej umowy zasadniczej (za Postanowieniem swoje głosy oddało 339 deputowanych ludowych). Postanowienie zawiera apel do UE, by uwzględniła ona $\mathrm{w}$ przyszłej umowie postęp dokonany w stosunkach Ukraina-UE, określiła perspektywy europejskiego rozwoju Ukrainy ${ }^{60}$. Zaproponowano również zapewnić dynamiczny rozwój relacji między Ukrainą a UE aż do nabycia przez Ukrainę członkostwa w tej organizacji; w perspektywie średniofalowej - udostępnić Ukrainie wewnętrzny rynek UE ${ }^{61}$. Ówczesny Prezydent W. Juszczenko niejednokrotnie wspominał o konieczności zasygnalizowania perspektywy nabycia przez Ukrainę członkostwa

57 J. Belinśka, Lutnewyj wizyt trijky ministriw zakordonnych spraw UE do Ukrajiny: formalnist' czy zakładennia sutnisnych pidwatyn majbutnich widnosyn Ukrajina-UE, „Polityka i czas” 2007, nr 3, s. 22-23.

58 J. Kyselowa, Ukrajina-UE: poczatok perehoworiw pro posyłenu uhodu, http://eu.prostir.ua/library/2513.html.

59 Ibidem.

60 Postanowa Werchownoji Rady Ukrajiny „Pro Zajadu Werchownoji Rady Ukrajiny "Pro zapoczatkuwannia perehoworiw miz Ukrajinoju ta UE szczoto układennia nowoho bazowoho dohoworu»”, „Widomosti Werchownoji Rady Ukrajiny” 2007, nr 16, poz. 223 .

61 Ibidem. 
w UE. Premier W. Janukowicz również niejednokrotnie wygłaszał eurointegracyjne hasła. Zwłaszcza podczas swojej wizyty do Brukseli jesienią 2006 r. powiedział, iż Ukraina jest gotowa, zrobić niezbędne kroki dla przystapienia do UE (walka z korupcja, reformy gospodarcze, przystapienie do Światowej Organizacji Handlu) ${ }^{62}$.

$\mathrm{Z}$ kolei UE odmawia w zamieszczeniu w nowej umowie punktu dotyczącego perspektywy członkostwa Ukrainy. Wysocy urzędnicy UE niejednokrotnie dają do zrozumienia, że nowa umowa nie będzie zawierała takiej perspektywy. Stwierdzono zwłaszcza o tym we wnioskach Rady UE z 22 stycznia 2007 r. $^{63}$

Podczas dwunastego szczytu Ukraina-UE w Paryżu 9 września 2008 r. została zatwierdzona nazwa nowej umowy między Ukrainą a UE - Umowa o stowarzyszeniu ${ }^{64}$. Postanowiono również, że będzie ona zawierała punkt o utworzeniu strefy wolnego handlu. Ukrainę uznano również za państwo, które ma wspólne z Europą wartości oraz historię.

Praktyka opracowywania, zawarcia i realizacji umów o stowarzyszeniu między UE a państwami trzecimi istotnie różni się. Stowarzyszenie europejskie jako rodzaj relacji stanowi zestaw elastycznych instrumentów politycznych o własnych parametrach, które rozwijają się i ulegają modyfikacji. Samo pojęcie „stowarzyszenia” jeszcze nie gwarantuje prawdziwej głębi relacji oraz ich treściwości.

Według stanu na kwiecień 2011 r. odbyło się 18 rund negocjacji w sprawie zawarcia nowej umowy między Ukrainą a UE.

Nierozwiązane nadal są następujące, zasadnicze sprawy. Po pierwsze, kwestia perspektywy członkostwa dla Ukrainy: UE nie jest nastawiona na to, by umowa o stowarzyszeniu z Ukrainą zawierała punkty dotyczące klarownej perspektywy członkostwa dla niej, z kolei władze ukraińskie nie są skłonne podpisywać umowę, która by nie zawierała takiej perspektywy.

Po drugie, nierozwiązaną pozostaje kwestia reżimu bezwizowego. W 2008 r. rozpoczęto tzw. „dialog wizowy” między Ukrainą a UE. W jego ramach przewidywano opracowanie i przyjęcie „Mapy drogowej” dla

62 J. Kyselowa, Ukrajina-UE..., http://eu.prostir.ua/library/2513.html.

63 Council Conclusions concerning the negotiation of a new enhanced Agreement between the EU and Ukraine, http://www.kmu.gov.ua/document/243135900/Вис-

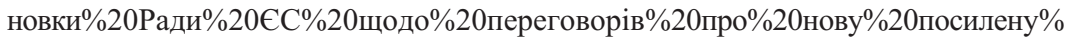
20угоду\%20між\%20Україною\%20та\%20СС\%20від\%2022.01.2007\%20(англ.).pdf.

64 Nazwa Umowy została uzgodniona 22 lipca 2008 r. w Brukseli przez ministrów ds. zagranicznych UE podczas posiedzenia Rady UE. 
reżimu bezwizowego między Ukrainą a UE na wzorzec tego, który został przyjęty dla państw Bałkan Zachodnich. Dialog prowadzony w trzech kierunkach: bezpieczeństwo dokumentów; walka z nielegalną migracją; porządek obywatelski oraz relacje zagraniczne. Wśród państw - członków UE nie ma konsensusu wobec kwestii wizowej. Liberalizację relacji wizowych z Ukrainą popierają państwa nadbałtyckie (Łotwa, Litwa, Estonia), skandynawskie (Finlandia, Szwecja) oraz „czwórka Wyszehradzka” (Polska, Czechy, Słowacja, Węgry), nie są przeciwne - Bułgaria oraz Rumunia. Inne państwa nastawione są mniej optymistycznie w tym zakresie. Zasadniczymi przeciwnikami są Francja oraz Niemcy. Borys Tarasiuk, znany ukraiński euroatlantysta, uważa, że nawet, gdy Ukraina wykona wszystkie zobowiązania i sprosta wszystkim wymaganiom, państwa te nie zmienia swojej postawy ${ }^{65}$.

Po trzecie, w zakresie utworzenia strefy wolnego handlu między Ukrainą a Unią Europejską pozostaje szereg nierozwiązanych problemów. Na przykład Ołeksandr Suszko wymienia następujące kwestie: dostęp ukraińskich przewoźników na rynek UE - Unia obawia się dumpingu z ich strony ${ }^{66}$; UE domaga się od Ukrainy zniesienia cła eksportowego na słonecznik - jest to czuły punkt, gdyż władze ukraińskie obawiają się, że w razie zniesienia tego cła eksportowane będą ziarna słonecznika, a nie olej ${ }^{67}$.

Po czwarte, nierozwiązane pozostają kwestie związane z dziedziną energetyczną. Niektóre państwa-członkowie UE wymagają, by w nowej umowie znalazły się konkretne gwarancje ze strony ukraińskiej dotyczące tranzytu zasobów energetycznych proponując dosyć niekorzystne dla Ukrainy rozwiązania (np. przelew kosztów na rachunek, z którego będą kompensowały się ryzyka) $)^{68}$.

\section{Podsumowanie}

Pisząc o europejskiej perspektywie Ukrainy należy wymienić bariery stojące na drodze jej eurointegracji. Po pierwsze, przekształcenia systemowe zachodzące na Ukrainie dotychczas nie zakończyły się wprowa-

\footnotetext{
65 O. Nabożniak, Wik Jewropy ne baczyty, http://news.finance.ua/ua/ /2/0/all/ 2010/02/09/186548/.

66 N. Majna, Ukrajina ta JeS - na finisznij priamij?, „Hławred” 17.06.11, http:/ua.glavred.info/archive/2011/06/17/085732-7.html.

67 Ibidem.

68 Ibidem.
} 
dzeniem demokracji skonsolidowanej. Ciagły stan przejścia, w którym znajduje się państwo ukraińskie, cechuje się częstymi zmianami konstytucji związanymi z wymianą elit rządzących, prześladowaniem przez sprawujących władzę swoich oponentów itp., co jest niedopuszczalne z punktu widzenia zasad UE. Po drugie, istotnym problemem (związanym ściśle z wcześniej wymienioną barierą) dla Ukrainy na drodze do UE jest wysoki wskaźnik korupcji. Transparency International w 2010 r. opublikowała Indeks Percepcji Korupcji, w którym Ukraina znalazła się na 134 pozycji wśród 178 krajów objętych badaniem. Ukraina otrzymała 2,4 punktów $^{69}$. Po trzecie, dane przeprowadzonych sondaży wskazują na ambiwalencję społeczeństwa ukraińskiego, które w zbliżonym stopniu opowiada się za przystapieniem do UE i zarazem do WEP. Po czwarte, nie można pominąć tzw. czynnika rosyjskiego. Im intensywniejsze stały się w 2011 r. negocjacje między UE a Ukrainą w sprawie utworzenia strefy wolnego handlu, tym częstsze stały się wizyty wysokich polityków Federacji Rosyjskiej na Ukrainie (w kwietniu 2011 r. odbyła się wizyta premiera Władimira Putina, w maju tegoż roku prezydenta FR Dmitrija Miedwiediewa), podczas których namawiają oni elity rządzące Ukrainy do szybkiego przystąpienia do WEP. Z tym że zaznaczają, iż Ukraina powinna określić się ze swoimi priorytetami. Po piąte, wśród państw członków UE nie ma konsensusu wobec aspiracji unijnych Ukrainy. Widać podziały wśród państw-członków UE w nastawieniu do Ukrainy chociażby w wyżej wymienionej sprawie wizowej.

\section{Ukrainian aspirations concerning the European Union}

\section{Summary}

The evolution of the ambitions of the Ukrainian authorities regarding integration with the EU is discussed in the paper. The current attitudes of political parties represented in Parliament towards the European Union, as well as the attitude of Ukrainian society towards the integration of the country with the EU is analyzed. Attention is focused on the Eastern Partnership as the EU's response to the aspirations of the Ukrainian political elites toward integration with the EU. The process of working out a new agreement between Ukraine and the $\mathrm{EU}$, that is to replace the Partnership and Cooperation Agreement, is analyzed. In the conclusions the principal barriers to the integration of Ukraine with the EU are highlighted.

69 Wyniki podawane są w skali od 0 do 10 punktów, przy czym im wyższa wartość indeksu tym poziom korupcji w danym kraju jest postrzegany jako niższy. 